\title{
Distribution of quinolone resistance gene (qnr) in ESBL-producing Escherichia coli and Klebsiella spp. in Lomé, Togo
}

Fortune Djimabi Salah ${ }^{1,2^{*}}$ (D), Serge Théophile Soubeiga ${ }^{1}$, Abdoul Karim Ouattara ${ }^{1}$, Adodo Yao Sadji ${ }^{2}$, Amana Metuor-Dabire ${ }^{1}$, Dorcas Obiri-Yeboah ${ }^{4}$, Abiba Banla-Kere ${ }^{2}$, Simplice Karou ${ }^{3}$ and Jacques Simpore ${ }^{1}$

\begin{abstract}
Background: Qnr genes are known to confer a low-level resistance to fluoroquinolone in Enterobacteriaceae. They are often found on the same resistance plasmids as extended spectrum $\beta$-lactamase (ESBL) and constitute the most common antibiotic resistance mechanism. This study aimed to detect the presence of qnr genes in ESBL-producing E. coli and Klebsiella spp.

Methods: From May 2013 to July 2015, 91 E. coli and 64 Klebsiella spp. strains with phenotypic resistance to quinolone were collected from several specimens and analyzed for the detection of anrA, anrB, anrS genes and the $\beta$-lactamase resistance genes (blaCTX-M, blaTEM, blaSHV) using simplex and multiplex PCR.

Results: In the present study, 107 (69\%; 61 E. coli and 46 Klebsiella spp.) of 155 bacterial strains tested were found harboring at least one qnr gene consisting of 74 (47.74\%) qnrB, 73 (47.10\%) gnrs and 4 (2.58\%) qnrA. Of the 107 strains encoding qur genes, 102, 96 and 52 carried CTX-M1, TEM and SHV type ESBL respectively.

Conclusion: This study identified quinolone resistance (qnr) gene in ESBL-producing E. coli and Klebsiella spp. in Togo. These finding which suggest a possible resistance to quinolone are of high interest for better management of patients and control of antimicrobial resistance in Togo.
\end{abstract}

Keywords: E. coli, Klebsiella spp., ESBL, Qnr gene, Togo

\section{Background}

Quinolones and $\beta$-lactams are classes of extensively used molecules worldwide in the treatment of many infectious diseases [1]. Quinolones are synthetic antibiotics used for infections involving Gram-negative bacteria such as Enterobacteriaceae. Fluoroquinolones have broad-spectrum intrinsic activity greater than quinolones [2].

Three main mechanisms of quinolone resistance have been described: i) the accumulation of mutations in the genes encoding quinolone target DNA gyrase and topoisomerase IV; ii) a decrease of intracellular concentration

\footnotetext{
* Correspondence: fortunedavi@yahoo.fr

'Biomolecular and Genetic Laboratory (LABIOGENE), Pietro Annigoni Biomolecular Research Center (CERBA), Department of

Biochemistry-Microbiology, University Ouaga I Prof Joseph Ki Zerbo, BP 364, Ouagadougou, Burkina Faso

2Bacteriology Laboratory, National Institute of Hygiene (INH), BP 1396, Lomé, Togo

Full list of author information is available at the end of the article
}

of fluoroquinolones by porins down-regulation or modification of the efflux pumps activity, iii) the acquisition of plasmid resistance genes [2].

The acquisition of plasmid-mediated quinolone resistance genes (PMQR) leads to the protection of quinolone's targets by qnr proteins belonging to the pentapeptide repeat (PRP) family and the hydrolysis of quinolones by the aac $\left(6^{\prime}\right)$-Ib-cr protein $[2,3]$. Mechanism of plasmid-mediated quinolone resistance leads to a low level of fluoroquinolone resistance and facilitates the selection of mutant strains with a high level of fluoroquinolone resistance $[3,4]$.

Since the discovery of plasmid quinolone resistance genes, a large number of $q n r$ alleles have been found on plasmids or bacterial chromosome. About 100 qnr genes variant have been described mainly from Enterobacteriaceae, and grouped into 5 distinct families: $q n r A$, qnrB, $q n r C, q n r D$ and $q n r S[3,5]$. 
Several surveys, based on molecular approaches, have found a strong association between qnr-positive and ESBL-positive isolates [5-8]. The presence of qur genes in ESBL-producing Enterobacteriaceae has been reported in Europe, United States, Asia and Africa [9-13]. In Niger, $q n r$ genes $(9.5 \%$ of $q n r A, 26.2 \%$ of $q n r B$ and $64.3 \%$ of $q n r S$ ) were found in ESBL-producing Enterobacteriaceae among fecal commensal of children with severe malnutrition [14].

In Togo, results from previous studies revealed the presence of beta-lactamase gene CTX-M1 (95.73\%), TEM (82.31\%) and $S H V(45.12 \%)$ in ESBL-producing E. coli and Klebsiella spp. The production of ESBL was associated with high co-resistance to fluoroquinolone (93\% for ciprofloxacin), aminoglycosides (76.36\% for gentamicin) and trimethoprim/sulfamethoxazole $(95.65 \%)$ [15, 16]. This high level of multidrug resistance suggests acquisition of plasmid-mediated antibiotic resistance factors in these strains. PMQR determinants as qnr genes was also usually found in multidrug resistance plasmid among Enterobacteriaceae producing-ESBL especially $E$. coli and species of Klebsiella [3, 6, 17, 18]. In this study we are interested in fluoroquinolone resistance. Here, we report the frequency of $q n r A, q n r B$ and $q n r S$ genes in ESBL-producing E. coli and Klebsiella spp.

\section{Methods}

\section{Samples collection and identification}

Well characterized Escherichia coli and Klebsiella spp. strains were collected during a prospective study from May 2013 to July 2015 in the bacteriology laboratory of the National Institute of Hygiene (INH) in Lomé, Togo. This public health institute is specialized in biomedical analysis, epidemiological surveillance, immunization, water, and food quality control. Strains were isolated from various pathological specimens including urine, vaginal swabs, pus, and sperm samples. Standard microbiological methods were used to isolate and purify bacterial strains on Mac-Conkey or Eosin Methylene Blue (EMB) media. Strains were identified using the API 20E identification system (API 20 E, Identification System for Enterobacteriaceae and others non-fastidious Gram-negative rod; BioMérieux, Marcy-Etoile, France). The API $20 \mathrm{E}$ system is a standardized technique allowing only the biochemical identification of an Enterobacterial strain using an isolated colony.

\section{Susceptibility test and ESBL phenotype detection}

Antibiotic susceptibility test was performed and interpreted according to the 2014 recommendations of Antibiogram Committee of the French Society of Microbiology [19].

Antibiotics were purchased from BioRad (Marnes-laCoquette, France) and included amoxicillin + clavulanate (AMC, 20/10 $\mu \mathrm{g})$, piperacillin-tazobactam (TZP, 75/10 $\mu \mathrm{g}$ ), cefoxitin (FOX, $30 \mu \mathrm{g})$, ceftriaxon (CRO, $30 \mu \mathrm{g})$, ceftazidim (CAZ, $30 \mu \mathrm{g})$, cefotaxim (CTX, $30 \mu \mathrm{g})$, cefepim (FEP, $30 \mu \mathrm{g})$, aztreonam (ATM, $30 \mu \mathrm{g})$, imipenem (IPM, $10 \mu \mathrm{g})$, amikacin (AKN, $30 \mu \mathrm{g})$, gentamicin (G, $15 \mu \mathrm{g}$ ), nalidixic acid (NA, $30 \mu \mathrm{g}$ ) ciprofloxacin (CIP, $5 \mu \mathrm{g}$ ), trimethoprimsulfamethoxazole (SXT 1.25/23,75 $\mu \mathrm{g}$ ), fosfomycin (FOS, $50 \mu \mathrm{g})$, doxycycline (DOX, $30 \mu \mathrm{g})$.

All isolates were subjected to the double disc synergy test for ESBL detection [20]. The presence of ESBL is detected by a synergy between ceftazidim and cefotaxim or ceftriaxon discs and amoxicillin + clavulanic acid disc.

E. coli ATCC 25922 strain was used as a control for antibiotic susceptibility testing.

Escherichia coli and Klebsiella spp. strains resistant to at least one third generation cephalosporin (cephalosporin, ceftazidim, ceftriaxon or cefotaxim) were collected in a storage medium (trypticase soy broth TCS) and stored at $-80{ }^{\circ} \mathrm{C}$. Samples were then sent under strict transportation conditions (in triple packaging boxes with ice packs), to Molecular Biology Laboratory of CERBA/LABIOGENE in Ouagadougou, Burkina Faso for $q n r$ and $E S B L$ genes detection on in January 2018.

\section{Extraction of bacterial DNA}

Rapid DNA extraction was performed using a boiling technique. Shortly, strains from TCS broth were reactivated on TCS agar for 18-24 $\mathrm{h}$ and two or three isolated colonies were inoculated in Luria Bertani (LB, $2 \mathrm{~mL}$ ). After 18-24 h of overnight culture, LB broth were centrifuged at $10000 \mathrm{rpm} / \mathrm{min}$ for $10 \mathrm{~min}$ and the pellet suspended in $500 \mu \mathrm{L}$ of phosphate buffer $(100 \mathrm{mM}, \mathrm{pH} 7)$ to cell-wall weakening. The mix was heated at $100{ }^{\circ} \mathrm{C}$ for $15 \mathrm{~min}$ in a water bath to release bacterial nucleic acid.

DNA was then precipitated in $250 \mu \mathrm{L}$ of absolute ethanol, washed twice in $1000 \mu \mathrm{L}$ of ethanol $75 \%$, dried and re-suspended in $100 \mu \mathrm{L}$ of sterile water.

\section{PCR amplification}

DNA samples $(5 \mu \mathrm{L})$ were subjected to multiplex PCR in a $25 \mu \mathrm{L}$ reaction mixture as previously described by Robicsek [21] for Qnr genes and Dallenne [22] for ESBL genes blaTEM and blaSHV using GeneAmp PCR System 9700 (Applied Biosystems, California USA).

Qnr genes ( $q n r A, q n r B$ and $q n r S$ ) amplification was performed using the following thermal cycling profile: 32 cycles consisting of $45 \mathrm{~s}$ at $95^{\circ} \mathrm{C}$ for denaturation, 45 $\mathrm{s}$ at $53^{\circ} \mathrm{C}$ for annealing and $60 \mathrm{~s}$ at $72{ }^{\circ} \mathrm{C}$ for extension.

For the blaTEM and blaSHV ESBL genes, multiplex PCR amplification conditions were as follows: initial denaturation step at $94{ }^{\circ} \mathrm{C}$ for $10 \mathrm{~min}$; 30 cycles of denaturation at $94{ }^{\circ} \mathrm{C}$ for $40 \mathrm{~s}$, annealing at $60{ }^{\circ} \mathrm{C}$ for 40 s, extension at $72{ }^{\circ} \mathrm{C}$ for $1 \mathrm{~min}$, followed by a final extension step at $72{ }^{\circ} \mathrm{C}$ for $7 \mathrm{~min}$. However, the amplification of BlaCTX-MG1 was carried out as previously described by Pagani [23] 
in $25 \mu \mathrm{L}$ reaction mixture according to the following PCR program: initial denaturation at $96^{\circ} \mathrm{C}$ for $10 \mathrm{~min} .35$ cycles of denaturation at $94^{\circ} \mathrm{C}$ for $1 \mathrm{~min}$, annealing at $50^{\circ} \mathrm{C}$ for $1 \mathrm{~min}$ and extension at $72^{\circ} \mathrm{C}$ for $1 \mathrm{~min}$. Final extension at $72^{\circ} \mathrm{C}$ for $10 \mathrm{~min}$. Negative (DNA from E. coli ATCC 25922) and positive controls (DNA from $q n r B$ and $S$ genes positive strains) were used to check potential unspecific amplification. Specific sequences primers provided by Applied Biosystems (California, USA) are shown in Table 1. DNA fragments were analyzed by electrophoresis in a $2 \%$ agarose gel at $100 \mathrm{~V}$ for $1 \mathrm{~h}$ in TBE $1 \mathrm{X}$ containing ethidium bromide using 100-bp DNA ladder (Promega, USA) as a size marker.

\section{Statistical analysis}

Statistical analysis was performed using Epi Info Version 7.1.1.14 software. Fisher's exact test was used for comparison and the difference was statistically significant when $p<0.05$.

\section{Results}

\section{Bacterial strains}

A sample of 155 strains, $91 \mathrm{E}$. coli and 64 Klebsiella spp. (55 Klebsiella pneumoniae and 9 Klebsiella oxytoca) resistant to at least one third generation cephalosporin (ceftazidim, cefotaxim or ceftriaxon) were collected during the study period. Bacteria were isolated from urine 91/155 (58.71\%), vaginal samples 38/155 (24.52\%), wound swabs $15 / 155$ (9.69\%), semen samples $6 / 155$ (3.87\%), urethral curettage $2 / 155$ (1.29\%), sputum $1 / 155$ (0.65\%), stool $1 / 155(0.65 \%)$ and joint fluid $1 / 155$ (0.65\%).

\section{Antibiotic susceptibility profile}

All $E$. coli strains were resistant to ceftriaxon and cefotaxim and $97.80 \%$ to ceftazidim. The resistance rates to other $\beta$-lactam antibiotics were $2.20 \%$ for imipenem (very low levels), $17.59 \%$ for piperacillin-tazobactam and

Table 1 Primers used for PCR amplification of qnr and bla genes identification

\begin{tabular}{|c|c|c|c|}
\hline Bla Genes & Sequence $\left(5^{\prime}-3^{\prime}\right)$ & Size (pb) & References \\
\hline qnrA & $\begin{array}{l}\text { For: ATTTCTCACGCCAGGATTTG } \\
\text { Rev:: GATCGGCAAAGGTTAGGTCA }\end{array}$ & 516 & [21] \\
\hline$q n r B$ & $\begin{array}{l}\text { For: GATCGTGAAAGCCAGAAAGG } \\
\text { Rev:: ACGATGCCTGGTAGTTGTCC }\end{array}$ & 469 & [21] \\
\hline anrs & $\begin{array}{l}\text { For: ACGACATTCGTCAACTGCAA } \\
\text { Rev:: TAAATTGGCACCCTGTAGGC }\end{array}$ & 417 & [21] \\
\hline TEM & $\begin{array}{l}\text { For: CATTTCCGTGTCGCCCTTATTC } \\
\text { Rev.: CGTTCATCCATAGTTGCCTGAC }\end{array}$ & 800 & [22] \\
\hline SHV & $\begin{array}{l}\text { For: AGCCGCTTGAGCAAATTAAAC } \\
\text { Rev.: ATCCCGCAGATAAATCACCAC }\end{array}$ & 713 & {$[22]$} \\
\hline CTX-M-G1 & $\begin{array}{l}\text { For: GTTACAATGTGTGAGAAGCAG } \\
\text { Rev:: CCGTTCCGCTATTACAAAC }\end{array}$ & 1000 & [23] \\
\hline
\end{tabular}

25.35\% for cefoxitin. Quinolones, nalidixic acid and ciprofloxacin were very inactive with rates of $96.67 \%$ and $94.51 \%$ respectively. Among aminoglycosides, the strains were more resistant to gentamicin (75.82\%) in contrast to amikacin which showed very low levels of resistance (3.30\%).

All Klebsiella spp. strains were resistant to cefepim. Resistance to ceftazidime and ceftriaxone was $98.44 \%$ (63/ 64) each one, and to cefotaxime $96.88 \%(62 / 64)$. Nalidixic acid, ciprofloxacin, doxycycline and trimethoprimsulfamethoxazole were also inactive antibiotics with at least a resistance rate of $90 \%$. Only imipenem, amikacin and fosfomycin were very active on Klebsiella spp. strains with a low resistance rate $(<5 \%)$. The resistance profile to other beta-lactams and other antibiotics for all isolates is presented in Table 2.

The ESBL were phenotypically detected in 87/91 (95.60\%) E. coli and 62/64 (96.88\%) Klebsiella spp. strains.

\section{Distribution of qnr genes}

Electrophoresis analysis revealed 107 strains (61 E. coli and 46 Klebsiella spp.) harboring at least one qnr gene: 74 (47.74\%) qnrB (41 E. coli and 33 Klebsiella spp.), 73 (47.10\%) qnrS (48 E. coli and 25 Klebsiella spp.) and 4 (2.58\%) qnrA (Klebsiella spp. only). However, any qnr genes were not detected in 48 strains. The concomitant presence of two or three qur genes was detected. An additional figure showed agarose gel electrophoresis in more detail (see Additional file 1). Proportions of qnrBS combinations were $30.77 \%$ and $18.75 \%$

Table 2 Antibiotic susceptibility profile

\begin{tabular}{|c|c|c|c|c|c|c|}
\hline \multirow[t]{2}{*}{ ATB } & \multicolumn{2}{|l|}{ E. coli } & \multicolumn{2}{|c|}{ Klebsiella spp } & \multicolumn{2}{|l|}{ Total } \\
\hline & $R(n / N)$ & R (\%) & $R(n / N)$ & R (\%) & $R(n / N)$ & R (\%) \\
\hline TZP & $16 / 91$ & 17.58 & $19 / 24$ & 29.69 & $35 / 155$ & 22.58 \\
\hline FOX & 18/71 & 25.35 & $12 / 52$ & 23.08 & $30 / 123$ & 24.39 \\
\hline CAZ & $89 / 91$ & 97.80 & $63 / 64$ & 98.44 & $152 / 155$ & 98.06 \\
\hline CRO & $91 / 91$ & 100 & $63 / 64$ & 98.44 & $154 / 155$ & 99.35 \\
\hline CTX & $91 / 91$ & 100 & $62 / 64$ & 96.88 & $153 / 155$ & 98.71 \\
\hline FEP & $89 / 91$ & 97.80 & $64 / 64$ & 100 & $153 / 155$ & 98.71 \\
\hline ATM & $90 / 91$ & 98.90 & $63 / 64$ & 98.44 & $153 / 155$ & 98.71 \\
\hline IMP & $2 / 91$ & 2.20 & $1 / 64$ & 1.56 & $3 / 155$ & 1.94 \\
\hline G & $69 / 91$ & 75.82 & $51 / 64$ & 79.69 & $120 / 155$ & 77.42 \\
\hline AKN & $3 / 91$ & 3.30 & $1 / 64$ & 1.56 & $4 / 155$ & 2.58 \\
\hline NA & $87 / 90$ & 96.67 & $51 / 63$ & 80.95 & $138 / 155$ & 90.20 \\
\hline CIP & $86 / 91$ & 94.51 & $58 / 64$ & 90.63 & $144 / 155$ & 92.90 \\
\hline FOS & $4 / 90$ & 4.44 & $3 / 64$ & 4.69 & $7 / 154$ & 4.55 \\
\hline SXT & $85 / 90$ & 94.44 & $56 / 61$ & 96.72 & $144 / 151$ & 95.36 \\
\hline DOX & $86 / 89$ & 96.63 & $58 / 63$ & 92.06 & $144 / 152$ & 94.74 \\
\hline
\end{tabular}


respectively in E. coli and Klebsiella spp.; qnrAS was observed in $3.13 \%$ of Klebsiella spp. while the triple association qurABS was found in one Klebsiella spp. strains. QnrA was not found in E. coli strains. The prevalence of $q n r$ genes was higher in Klebsiella spp. 71.88\% (46/64) compared to E. coli $67.03 \%$ (61/91) strains. Distribution of $q n r$ genes in bacterial species is shown in Fig. 1.

\section{Antibiotic susceptibility profile of qnr-positive strains}

Out of the 107 (61 E. coli +46 Klebsiella spp.) strains encoding qnr genes, 95/105 (90.48\%) were resistant to nalidixic acid (58 E. coli +37 Klebsiella spp.) and 100/107 (93.46\%) were resistant to ciprofloxacin (57 E. coli +43 Klebsiella spp.); 105/107 (98.13\%) resistant to ceftazidim (59 E. coli +46 Klebsiella spp.) and 106/107 (99.07\%) to ceftriaxon (61 E. coli +45 Klebsiella spp.). The resistance rates to gentamicin were $82.24 \%(88 / 107)$.

These strains remained however susceptible to imipenem (97.20\%), amikacin (97.20\%), and fosfomycin (95.33\%). The resistance profile is presented in Table 3.

Most isolates that were resistant to ciprofloxacin and nalidixic acid encoded $q n r B$ and $q n r S$ alone or in association but no qnr genes was detected in $29 \mathrm{E}$. coli and 15 Klebsiella spp. strains resistant to ciprofloxacin and nalidixic acid. Nevertheless, isolates encoding qnrB or qnrS were also identified among nalidixic acid-susceptible (10/ 105) and ciprofloxacin-susceptible strains (7/107) (Table 4).

Distribution of qnr genes among ESBL-producing isolates PCR was performed to determine the presence of $E S B L$ genes and all strains, positive or not to the double disc synergy test, carried at least one genes
Table 3 Antibiotic susceptibility profile of anr positive strains

\begin{tabular}{|c|c|c|c|c|c|}
\hline \multirow[t]{2}{*}{ ATB } & & \multirow[t]{2}{*}{ E. coli } & \multirow{2}{*}{$\begin{array}{l}\text { Klebsiella } \\
\text { spp. }\end{array}$} & \multicolumn{2}{|l|}{ Total } \\
\hline & & & & $\mathrm{n} / \mathrm{N}$ & $\%$ \\
\hline \multirow[t]{2}{*}{ NA } & R & $58 / 60$ & $37 / 45$ & $95 / 105$ & 90.48 \\
\hline & S & $2 / 60$ & $8 / 45$ & $10 / 105$ & 9.52 \\
\hline \multirow[t]{2}{*}{ CIP } & $\mathrm{R}$ & $57 / 61$ & $43 / 46$ & 100/107 & 93.46 \\
\hline & S & $4 / 61$ & $3 / 46$ & $7 / 107$ & 6.54 \\
\hline \multirow[t]{2}{*}{ CAZ } & R & $59 / 61$ & $46 / 46$ & $105 / 107$ & 98.13 \\
\hline & S & $2 / 61$ & $0 / 46$ & $2 / 107$ & 1.87 \\
\hline \multirow[t]{2}{*}{ CRO } & R & $61 / 61$ & $45 / 46$ & 106/107 & 99.07 \\
\hline & S & $0 / 61$ & $1 / 46$ & $1 / 107$ & 0.93 \\
\hline \multirow[t]{2}{*}{ IMP } & R & $2 / 61$ & $1 / 46$ & $3 / 107$ & 2.80 \\
\hline & S & $59 / 61$ & $45 / 46$ & $104 / 107$ & 97.20 \\
\hline \multirow[t]{2}{*}{ AKN } & R & $2 / 61$ & $1 / 46$ & $3 / 107$ & 2.80 \\
\hline & S & $59 / 61$ & $45 / 46$ & $104 / 107$ & 97.20 \\
\hline \multirow[t]{2}{*}{ G } & R & $48 / 61$ & $40 / 46$ & $88 / 107$ & 82.24 \\
\hline & S & $13 / 61$ & $6 / 46$ & 19/107 & 17.76 \\
\hline \multirow[t]{2}{*}{ FOS } & R & $4 / 61$ & $1 / 46$ & $5 / 107$ & 4.67 \\
\hline & S & $57 / 61$ & $45 / 46$ & $102 / 107$ & 95.33 \\
\hline
\end{tabular}

$R$ resistant, $S$ sensible, $C A Z$ ceftazidim, $C R O$ ceftriaxon, IPM imipenem, $G$ gentamicin, AKN amikacin, NA nalidixic acid, CIP ciprofloxacin, FOS fosfomycin

blaTEM, blaSHV and/or blaCTX-M1. All E. coli and Klebsiella spp. strains qnr positive were ESBLproducing. Within the 107 strains encoding qnr genes (61 E. coli +46 Klebsiella spp.), 102 carried CTX-M1 (59 E. coli +43 Klebsiella spp.), 96 carried TEM (54 E. coli +42 Klebsiella spp.) and 52 carried SHV (17 E. coli +35 Klebsiella spp.).

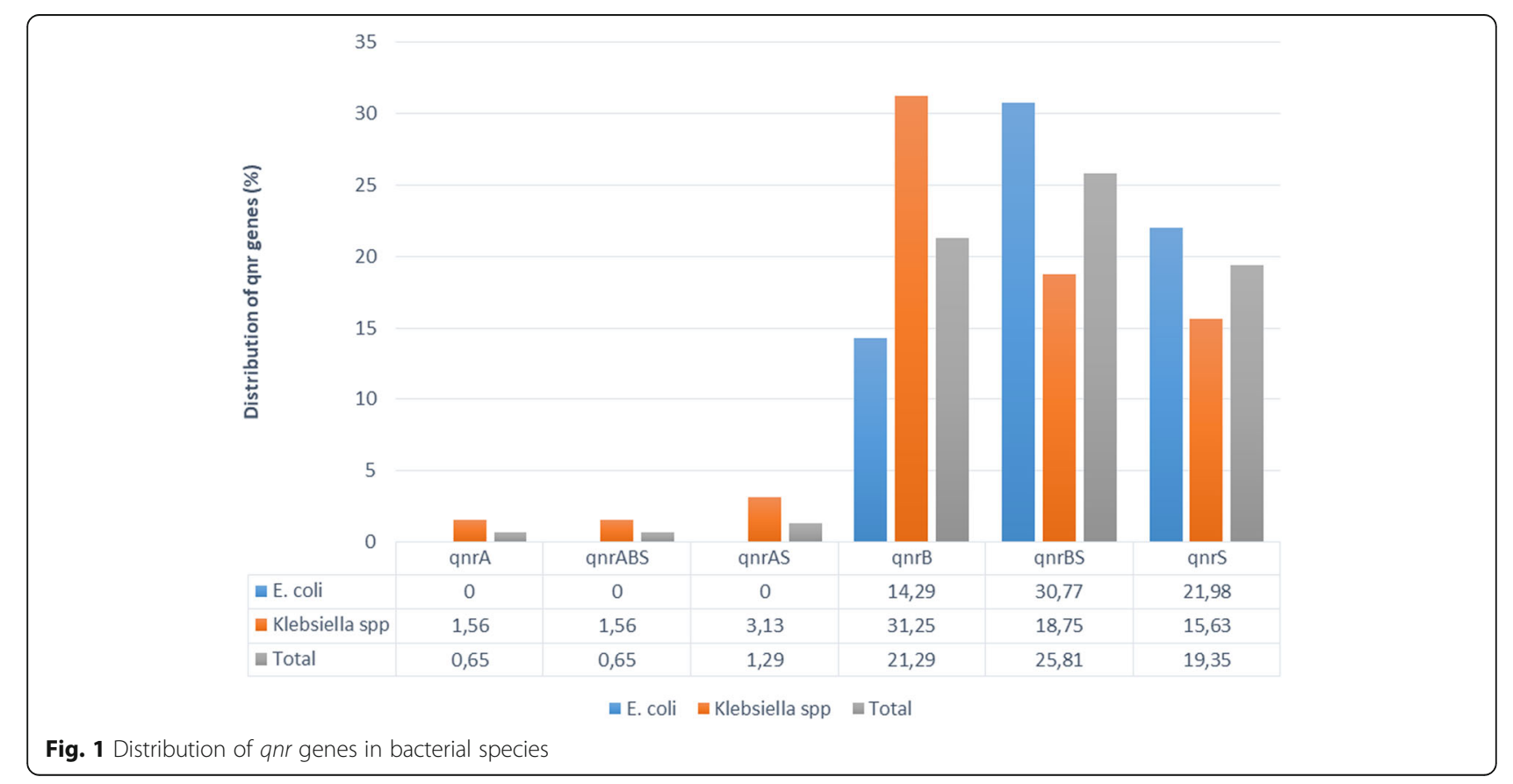


Table 4 Co-existence of qnr gene and bla gene in E. coli and Klebsiella spp.

\begin{tabular}{|c|c|c|c|c|c|c|c|c|c|c|c|c|}
\hline \multirow{2}{*}{$\frac{\text { Species }}{\text { Qnr gene }}$} & & \multicolumn{4}{|c|}{ E. coli $(N=61)$} & \multicolumn{7}{|c|}{ Klebsiella spp $(N=46)$} \\
\hline & & $\begin{array}{l}\text { anrB } \\
(n=13)\end{array}$ & $\begin{array}{l}\text { qnrBS } \\
(n=28)\end{array}$ & $\begin{array}{l}\text { gnrs } \\
(n=20)\end{array}$ & Total 1 & $\begin{array}{l}\text { gnrA } \\
(n=1)\end{array}$ & $\begin{array}{l}\text { qnrABS } \\
(n=1)\end{array}$ & $\begin{array}{l}\text { qnrAS } \\
(n=2)\end{array}$ & $\begin{array}{l}q n r B \\
(n=20)\end{array}$ & $\begin{array}{l}\text { qnrBS } \\
(n=12)\end{array}$ & $\begin{array}{l}\text { gnrs } \\
(n=10)\end{array}$ & Total 2 \\
\hline \multirow[t]{2}{*}{ NA } & $\mathrm{R}$ & 12 & 28 & 18 & 58 & 1 & 1 & 2 & 17 & 10 & 6 & 37 \\
\hline & S & 1 & 0 & 1 & 2 & 0 & 0 & 0 & 2 & 2 & 4 & 8 \\
\hline \multirow[t]{2}{*}{ CIP } & $\mathrm{R}$ & 11 & 28 & 18 & 57 & 1 & 1 & 2 & 20 & 11 & 8 & 43 \\
\hline & S & 2 & 0 & 2 & 4 & 0 & 0 & 0 & 0 & 1 & 2 & 3 \\
\hline \multirow[t]{6}{*}{ ESBL genes } & CTX-M1 & 2 & 4 & 1 & 7 & 0 & 0 & 0 & 0 & 0 & 0 & 0 \\
\hline & SHV CTX-M1 & 0 & 0 & 0 & 0 & 0 & 0 & 0 & 0 & 3 & 1 & 4 \\
\hline & TEM & 0 & 0 & 1 & 1 & 0 & 0 & 0 & 0 & 0 & 0 & 0 \\
\hline & TEM CTX-M1 & 6 & 16 & 14 & 36 & 0 & 1 & 0 & 5 & 2 & 3 & 11 \\
\hline & TEM SHV & 0 & 0 & 1 & 1 & 0 & 0 & 0 & 1 & 2 & 0 & 3 \\
\hline & TEM SHV CTX-M1 & 5 & 8 & 3 & 16 & 1 & 0 & 2 & 14 & 5 & 6 & 28 \\
\hline
\end{tabular}

$R$ resistant, $S$ sensible, NA nalidixic acid, CIP ciprofloxacin, ESBL extended spectrum $\beta$-lactamase, qnr quinolone resistance

Results revealed that qnr subtypes $(A, B, S)$ could coexist alone or in association with blaCTX-M1, blaTEM and blaSHV. Among E. coli strains, qnrBS combinations was most frequently associated with TEM/CTX-M1 combinations and among Klebsiella spp., the most frequent association was qnrB plus TEM/SHV/CTX-M1 (Table 4).

\section{Discussion}

Plasmid-mediated quinolone resistance may facilitate the spread and increase frequency of quinolone-resistant strains. Until now $q n r$ genes have been widely detected in different parts of the world. Such data are not available in Togo. This is the first study which reports the frequency and diversity of qnr genes among ESBLproducing Enterobacteriaceae in Togo.

The highest rate was found among Klebsiella spp. (71.88\%) and E. coli (67.03\%). Three $q n r$ groups were detected and are described in this report. Among all the isolates detected, $q n r B(47.74 \%)$ and $q n r S(47.10 \%)$ were the most predominant, followed by qnrA (2.58\%).

These frequencies found in this study are higher than those reported in Côte d'Ivoire where qnr genes were found at $31.2 \%$ in E. coli and $20.5 \%$ in Klebsiella spp. with $14.6 \%$ for $q n r B, 9.9 \%$ for $q n r A$ and $2.7 \%$ for $q n r A S$ [10]. Always in Côte d'Ivoire, others authors found $50.54 \%$ of $q n r$ genes in Klebsiella pneumoniae $(71.73 \%$ $q n r B, 26.08 \%$ qnrS and $2.17 \%$ qnrA) [24].

In Niger, $q n r$ genes were also reported at $93.3 \%$ in Klebsiella spp. and $44.4 \%$ in E. coli with $64.3 \%$ for $q n r S$, $26.2 \%$ for $q n r B$ and $9.5 \%$ for $q n r A$ [14].

In Morocco, $q n r B$ was found at 23\%, qnr $A$ at $10 \%$ and $q n r S$ at $3 \%$ in $50 \%$ Klebsiella spp. and $18.7 \%$ E. coli [9]. In 2014 in Moroccan community enterobacteria, the prevalence of $q n r$ gene was $2.6 \%$ (1.7\% qnrS1 and $0.9 \%$ qnrB) [25]. These genes are usually plasmid mediated and can easily spread among the members of Enterobacteriaceae, through gene transfer mechanisms $[3,6,17,18]$. Results of plasmid isolation test and conjugation experiments in different studies indicated that these $q n r$ gene were carried by conjugative plasmid of high molecular weight. These determinants can be transferred between bacteria, thus realizing the epidemic spread of quinolone resistance through horizontal gene transfer [11, 13, 25-28]. However, due to the lack of financial resources, conjugation experiments or hybridization confirming the presence of target genes on plasmids were not performed in the present study.

Among strains encoding the $q n r$ gene in our study, $90.48 \%$ were resistant to nalidixic acid, $93.46 \%$ to ciprofloxacin, $98.13 \%$ to ceftazidim and $99.07 \%$ to ceftriaxon. These rates are higher than those observed in Morocco (57\% for nalidixic acid and $78 \%$ ciprofloxacin, $100 \%$ for ceftazidim and $71 \%$ for cefotaxim) [9]. In Mexico, the resistance rate among qur positive pediatric strains was $41.1 \%$ for nalidixic acid, $29.4 \%$ for ciprofloxacin, $82.3 \%$ for ceftazidim and $100 \%$ for cefotaxim [13]. In this study, higher resistance rate of the qnr positive strains against nalidixic acid and ciprofloxacin could be explained by the concomitant presence of two or three $q n r$ gene groups $(43 / 107,40.20 \%)$, also found in Algeria and in Vietnam, thus inducing an additive effect on the minimal inhibiting concentration (MICs) of these different molecules. In addition, $q n r$ positive isolates showed more resistance to gentamicin $(82.24 \%)$. This may be explained by the fact that plasmid-mediated quinolone resistance is associated with integrons bearing resistance determinants to several other antibiotics such as betalactams and aminoglycosides [3, 4, 27, 29]. The $q n r$ genes were identified among isolates which were susceptible to nalidixic acid and ciprofloxacin.

This result has clinical implications since the acquisition of the $q n r$ genes by quinolone susceptible ESBLproducing strains could lead to selection of ciprofloxacin and cephalosporin resistant strains an increasing the 
mutant prevention concentration (MPC) [6, 17]. However no qur genes was detected in $29 \mathrm{E}$. coli and 15 Klebsiella spp. strains resistant to ciprofloxacin and nalidixic acid, can suggest the presence of another mechanism of resistance to quinolones such as mutations in the gyrase and topoisomerase IV genes [2, 6, 30].

The presence of ESBL and some of the quinoloneresistant genes in the same mobile genetic elements could explain the co-resistance to beta-lactams and fluoroquinolones. Our results showed that all E. coli and Klebsiella spp. strains qnr positive were ESBL-producing. Among qnr-positive strains, 102 produce CTX-M1, 52 $S H V$ and 96 produce TEM.

Previous studies showed that $q n r$-positive strains frequently expressed ESBL [9-11, 28, 31, 32]. The strong association between PMQR gene and blaCTX-M-15 and blaTEM-116 was detected in clinical Enterobacterial isolates from Iran [31]. In Mexico, characterization of adult $q n r$-positive isolates indicated that the SHV ESBL-type (SHV-12, -5, and 2a) was the most prevalent (81.6\%) followed by CTX-M-15 (44.9\%) [28]; but in pediatric isolates, CTX-M-15 was the most predominant (70.5\%) [13]. However, in both bacterial population, combination of $E S B L$ and $q n r$ genes may be pointing to a co-selection of cephalosporin and quinolone resistance. QnrA1 and qnrS1 have previously been found to be associated with blaCTX$M-9$, blaSHV-12 and blaSHV-92 among Enterobacterial isolates in Spain [11]. QnrB was observed to be coproduced with CTX-M-15 in Algeria strains of E. coli [33]. A similar result was recently found in Klebsiella pneumoniae isolates from Côte d'Ivoire, but the type of ESBL was not determined [24]. Qnr genes are usually found in multi-resistance plasmids linked to other resistance determinants, beta-lactamase genes have been conspicuously common $[5,6,25,26]$.

Our results also revealed that qnr subtypes could coexist alone or in association with beta-lactamase genes.

Among E. coli strains, qnrBS combinations was most frequently associated with blaTEM/CTX-M1 combinations and among Klebsiella spp., the most frequent association was qnrB plus blaTEM/SHV/CTX-M1. The blaCTX-M1, plasmid-mediated class A ESBL [34-36] expression was observed to be currently more frequent in a double or triple combination with blaTEM and blaSHV. This genes combination suggests a progressive consolidation of resistance genes on a single mobile genetic element (plasmids, integrons, etc.).

These findings raise the hypothesis that the qnr genes detected in these strains could also have the same plasmid location. Plasmid isolation and conjugation experiments should be then investigated to confirm the presence of target genes on plasmids. Our results also suggested the community emergence of $P M Q R$ determinants (qnr gene) that contributed to the development and spread of fluoroquinolone resistance in E. coli and Klebsiella spp. isolates in Togo. The presence of these determinants in the outpatient is worrisome, due of the potential spread of plasmids in a scenario of uncontrolled oral quinolone usage, which can compromise therapeutic options and therefore concern for public health.

The potential limitations of this study were the absence of data on minimal inhibiting concentration (MIC) for nalidixic acid and ciprofloxacin to determine the level of bacterial resistance to these antibiotics and also the bias of including only $E S B L$ strains and the absence of molecular typing of strains and sequence analysis of the different genes.

Altogether, the results of the present study underline the frequency of $q n r$ determinants associated to fluoroquinolones resistance among E. coli and Klebsiella spp ESBLproducing strains in Togo and identifies the presence of $q n r$ genes in quinolone-susceptible strains which could lead to in vivo selection of ciprofloxacin-resistant strains.

\section{Conclusion}

This first report of qnrA, qnrB and qnrS gene among ESBL-producing E. coli and Klebsiella spp. from Togo, extends upon similar finding in many countries supporting the wide distribution of $q n r$ genes.

The results revealed a high rate of qnrB and qnrS alone or in combination and a higher association with blaTEM/CTX-M1 and blaTEM/SHV/CTX-M1 combinations. These $q n r$ genes positive strains were highly resistant to nalidixic acid, ciprofloxacin, ceftazidim, ceftriaxon and gentamycin. However, they remain susceptible to imipenem, amikacin and fosfomycin.

The plasmid-mediated quinolone resistance genes and their association with cephalosporin resistance mediated by $E S B L$ contribute to the spread of multidrug resistance due to their easy transfer between bacteria. Their wide dissemination impairs treatment outcome of common infections in community and hospitals settings. These finding suggest the strengthening of the public health policies in Togo in order to prevent, monitor and control antimicrobial resistance through the implementation of an antibiotic resistance surveillance system. Further studies on sequence analysis of the $E S B L$ gene amplicons are also needed to determine different resistance profile of $E S B L$-producing bacteria in Togo.

\section{Additional file}

Additional file 1: Agarose gel electrophoresis (2\%) used for the separation of multiplex PCR products. M: molecular size marker (100 bp ladder, Promega, USA); line 1, 8, 9, 12: negative; line 2, 4, 5, 7, 10, 11, 14, 15, 17, 18, 19, 20: qnr B + qur $S$ genes: line 3: qnr $A+$ qnr $B+$ qnr $S$ genes; line 6: qnrS genes; line 13: qnrB genes; line 21: negative control and line 22: positive control qnrB genes. Qnr A (517 bp), qnrB (469 bp), qnr S (417 bp). (PDF 325 kb) 


\section{Abbreviations}

AKN: Amikacin; AMC: Amoxicillin + clavulanate; ATCC: American Type Culture Collection; ATM: Aztreonam; CASFM/EUCAST: Comité d'Antibiogramme de la Socièté Française de Microbiologie/EUropean Committee on Antimicrobial Susceptibility Testing; CAZ: Ceftazidim; CERBA: Centre de Recherche Biomoléculaire Pietro Annigoni; CIP: Ciprofloxacin; CRO: Ceftriaxon; CTX: Cefotaxim; CTX-M: Cefotaximase-Munich; DNA: Desoxyribonucleic Acid; DOX: Doxycyclin; EMB: Eosin Methylene Blue; ESBL: Extended Spectrum BetaLactamase; ESTBA: Ecole Supérieure des Techniques Biologique et Alimentaire; FEP: Cefepim; FOS: Fosfomycin; FOX: Cefoxitin; G: Gentamycin; IMP: Imipenem; INH: Institut National d'Hygiène; LABIOGENE: Laboratoire de Biologie Moléculaire et de Génétique Moléculaire; NA: Nalidixic acid; PMQR: Plasmid Mediated Quinolone Resistance; PRP: Pentapeptid Repeat Protein; qnr: quinolone resistance; SHV: Sulfhydryl Variable; SXT: trimethoprim/sulfamethoxazole; TCS: Trypticase Soy; TEM: Temoniera; TZP: Piperacillin-tazobactam

\section{Acknowledgements}

FDS is grateful to the 2018 Mwalimu Nyerere African Union Scholarship scheme for an enrolment in PhD in molecular biology and genetics at the University of Ouaga I Prof Joseph Ki-Zerbo, Burkina Faso. We also thank the WAEMU Commission, through the PACER II program granted the molecula biology laboratory CERBA/LABIOGENE University Ouaga I Prof. Joseph KiZerbo for the realization of molecular biology analysis.

We thank Kossi Komlan and Maman Issaka for their advice and suggestions.

\section{Authors' contributions}

FDS, AYS and JS designed the study; FDS, STS and AKO performed the experiments, analyzed the data and drafting the manuscript. FDS, DOY, AMD, ABK, SK and JS were involved in critically reviewing the manuscript. All authors have read and approved the final version.

\section{Funding}

Not applicable.

\section{Availability of data and materials}

The database analyzed during the study is available on reasonable request from the corresponding author.

\section{Ethics approval and consent to participate}

This study received the INH approval for the transfer of strains, to the molecular biology laboratory of CERBA/ LABIOGENE, University Ouaga I Professor Joseph Ki-Zerbo, Burkina Faso. The institutional ethic committee of CERBA/LABIOGENE reviewed and approved the study protocol.

\section{Consent for publication}

Not applicable. This study does not contain any individual or personal data.

\section{Competing interests}

The authors declare that they have no competing interests.

\section{Author details}

'Biomolecular and Genetic Laboratory (LABIOGENE), Pietro Annigoni Biomolecular Research Center (CERBA), Department of Biochemistry-Microbiology, University Ouaga I Prof Joseph Ki Zerbo, BP 364 Ouagadougou, Burkina Faso. ${ }^{2}$ Bacteriology Laboratory, National Institute of Hygiene (INH), BP 1396, Lomé, Togo. ${ }^{3}$ High School of Biological and Food Techniques (ESTBA), University of Lomé, BP 1515, Lomé, Togo. ${ }^{4}$ Department of Microbiology and Immunology, School of Medical Sciences, University of cape Coast, PMB, Cape Coast, Ghana.

\section{Received: 17 January 2019 Accepted: 4 June 2019}

Published online: 18 June 2019

\section{References}

1. Adriaenssens N, Coenen S, Versporten A, Muller A, Minalu G, Faes C, et al. European surveillance of antimicrobial consumption (ESAC): outpatient antibiotic use in Europe (1997-2009). J Antimicrob Chemother. 2011; 66(Suppl 6):vi3-12.

2. Jacoby GA. Mechanisms of resistance to quinolones. Clin Infect Dis. 2005; 41(Suppl 2):S120-6.
3. Strahilevitz J, Jacoby GA, Hooper DC, Robicsek A. Plasmid-mediated quinolone resistance: a multifaceted threat. Clin Microbiol Rev. 2009;22(4): 664-89.

4. Muylaert A, Mainil J, editors. Résistances aux fluoroquinolones: la situation actuelle. Annales de Médecine Vétérinaire; 2013: Université de Liège.

5. Nordmann P, Poirel L. Emergence of plasmid-mediated resistance to quinolones in Enterobacteriaceae. J Antimicrob Chemother. 2005;56(3): 463-9.

6. Jacoby GA, Strahilevitz J, Hooper DC. Plasmid-mediated quinolone resistance. Microbiol Spectr. 2014;2(5).

7. Jacoby GA, Walsh KE, Mills DM, Walker VJ, Oh H, Robicsek A, et al. qnrB, another plasmid-mediated gene for quinolone resistance. Antimicrob Agents Chemother. 2006;50(4):1178-82.

8. Robicsek A, Jacoby GA, Hooper DC. The worldwide emergence of plasmidmediated quinolone resistance. Lancet Infect Dis. 2006;6(10):629-40.

9. Bouchakour M, Zerouali K, Gros Claude JD, Amarouch H, El Mdaghri N, Courvalin $\mathrm{P}$, et al. Plasmid-mediated quinolone resistance in expanded spectrum beta lactamase producing enterobacteriaceae in Morocco. J Infect Dev Ctries. 2010;4(12):779-803.

10. Guessennd N, Bremont S, Gbonon V, Kacou-Ndouba A, Ekaza E, Lambert T, et al. Qnr-type quinolone resistance in extended-spectrum beta-lactamase producing enterobacteria in Abidjan, Ivory Coast. Pathologie-biologie. 2008; 56(7-8):439-46.

11. Lavilla S, Gonzalez-Lopez JJ, Sabate M, Garcia-Fernandez A, Larrosa MN, Bartolome RM, et al. Prevalence of qur genes among extended-spectrum beta-lactamase-producing enterobacterial isolates in Barcelona, Spain. J Antimicrob Chemother. 2008;61(2):291-5.

12. Poirel L, Leviandier C, Nordmann P. Prevalence and genetic analysis of plasmid-mediated quinolone resistance determinants QnrA and QnrS in Enterobacteriaceae isolates from a French university hospital. Antimicrob Agents Chemother. 2006;50(12):3992-7

13. Silva-Sanchez J, Cruz-Trujillo E, Barrios H, Reyna-Flores F, Sanchez-Perez A, Bacterial Resistance C, et al. Characterization of plasmid-mediated quinolone resistance $(\mathrm{PMQR})$ genes in extended-spectrum beta-lactamase-producing Enterobacteriaceae pediatric clinical isolates in Mexico. PLoS One. 2013; 8(10):e77968.

14. Moumouni A, Diagbouga S, Nadembèga C, Metuor Dabire A, Ouattara K, Zohoncon T, et al. Quinolone Resistance (qnr) genes in fecal carriage of extended Spectrum beta-lactamases producing Enterobacteria isolated from children in Niger. Curr Res Microbiol Biotechnol. 2017;5(1):953-7.

15. Diagbouga S, Salah FD, Sadji AY, Metuor Dabire A, Nadembega C, Banla Kere A, et al. Detection of high prevalence of TEM/SHV/CTX-M genes in ESBL producing and multidrug resistant Klebsiella Pneumoniae and Klebsiella Oxytoca. J Clin Diagn Res. 2016;4(1:130):p7.

16. Salah FD, Diagbouga S, Metuor Dabire A, Sadji AY, Nadembega C, Moumouni A, et al. First detection of Resistance genes encoding extended Spectrum $\beta$-lactamase producing Escherichia coli at Lomé, Togo. Arch Clin Microbiol. 2017;7(6):p7

17. Martinez-Martinez L, Pascual A, Jacoby GA. Quinolone resistance from a transferable plasmid. Lancet. 1998;351(9105):797-9.

18. Tran JH, Jacoby GA. Mechanism of plasmid-mediated quinolone resistance. Proc Natl Acad Sci. 2002;99(8):5638-42.

19. CASFM/EUCAST. Recommendations 2014 V1.0 Mai 2014. Paris, FRANCE: Socièté Française de Microbiologie; 2014. p. 114.

20. Jarlier V, Nicolas MH, Fournier G, Philippon A. Extended broad-spectrum beta-lactamases conferring transferable resistance to newer beta-lactam agents in Enterobacteriaceae: hospital prevalence and susceptibility patterns. Rev Infect Dis. 1988;10(4):867-78.

21. Robicsek A, Strahilevitz J, Sahm DF, Jacoby GA, Hooper DC. Qnr prevalence in ceftazidime-resistant Enterobacteriaceae isolates from the United States. Antimicrob Agents Chemother. 2006;50(8):2872-4

22. Dallenne C, Da Costa A, Decre D, Favier C, Arlet G. Development of a set of multiplex PCR assays for the detection of genes encoding important betalactamases in Enterobacteriaceae. J Antimicrob Chemother. 2010;65(3): 490-5.

23. Pagani L, Dell'Amico E, Migliavacca R, D'Andrea MM, Giacobone $E_{1}$ Amicosante G, et al. Multiple CTX-M-type extended-spectrum betalactamases in nosocomial isolates of Enterobacteriaceae from a hospital in northern Italy. J Clin Microbiol. 2003;41(9):4264-9.

24. Tahou JE, Guessennd N, Sokouri PD, Gbonon V, Konan F, Kouadio J, et al. Antimicrobial Resistance of Klebsiella pneumoniae -ESBL producing strains 
isolated from clinical specimens in Abidjan (cote de Ivoire). Microbiol Res J Int. 2017;20(2):1-7.

25. Jamali L, Haouzane F, Bouchakour M, Oufrid S, Ghazlane Z, El Mdaghri N, et al. Prévalence des gènes de résistance plasmidique aux quinolones chez des entérobactéries communautaires isolées au Maroc [Prevalence of plasmid mediated quinolone resistance genes among enterobacteria isolates in Moroccan community]. Int J Innov Sci Res. 2014;11(2):387-99.

26. Barguigua A, El Otmani F, Talmi M, Reguig A, Jamali L, Zerouali K, et al. Prevalence and genotypic analysis of plasmid-mediated $\beta$-lactamases among urinary Klebsiella pneumoniae isolates in Moroccan community. J Antibiotics. 2013;66(1):11.

27. Minh Vien LT, Baker S, Phuong Thao LT, Phuong Tu LT, Thu Thuy C, Thu $\mathrm{Nga} T \mathrm{~T}$, et al. High prevalence of plasmid-mediated quinolone resistance determinants in commensal members of the Enterobacteriaceae in $\mathrm{Ho}$ Chi Minh City. Vietnam J Med Microbiol. 2009:58(12):1585-92.

28. Silva-Sanchez J, Barrios H, Reyna-Flores F, Bello-Diaz M, Sanchez-Perez A, Rojas $T$, et al. Prevalence and characterization of plasmid-mediated quinolone Resistance genes in extended-Spectrum $\beta$-lactamaseproducing Enterobacteriaceae isolates in Mexico. Microb Drug Resist. 2011;17(4):497-505

29. labadene H, Messai Y, Ammari H, Ramdani-Bouguessa N, Lounes S, Bakour $R$, et al. Dissemination of ESBL and Qnr determinants in Enterobacter cloacae in Algeria. J Antimicrob Chemother. 2008;62(1):133-6.

30. Redgrave LS, Sutton SB, Webber MA, Piddock LJV. Fluoroquinolone resistance: mechanisms, impact on bacteria, and role in evolutionary success. Trends Microbiol. 2014;22(8):438-45.

31. Azargun R, Sadeghi MR, Soroush Barhaghi MH, Samadi Kafil H, Yeganeh F, Ahangar Oskouee $\mathrm{M}$, et al. The prevalence of plasmid-mediated quinolone resistance and ESBL-production in Enterobacteriaceae isolated from urinary tract infections. Infect Drug Resist. 2018;11:1007-14.

32. Sedighi I, Arabestani MR, Rahimbakhsh A, Karimitabar Z, Alikhani MY. Dissemination of extended-spectrum $\beta$-lactamases and quinolone resistance genes among clinical isolates of uropathogenic Escherichia coli in children. Jundishapur J Microbiol. 2015;8(7):e19184.

33. Betitra Y, Teresa V, Miguel V, Abdelaziz T. Determinants of quinolone resistance in Escherichia coli causmg community-acquired urinary tract infection in Bejaia, Algeria. Asian Pac J Trop Med. 2014;7:462-7.

34. Bonnet R. Growing group of extended-spectrum beta-lactamases: the CTXM enzymes. Antimicrob Agents Chemother. 2004;48(1):1-14.

35. Poirel L, Decousser J-W, Nordmann P. Insertion sequence ISEcp1B is involved in expression and mobilization of a blaCTX-M $\beta$-lactamase gene. Antimicrob Agents Chemother. 2003;47(9):2938-45.

36. Poirel L, Naas T, Nordmann P. Genetic support of extended-spectrum betalactamases. Clin Microbiol Infect. 2008:14(Suppl 1):75-81.

\section{Publisher's Note}

Springer Nature remains neutral with regard to jurisdictional claims in published maps and institutional affiliations.

Ready to submit your research? Choose BMC and benefit from:

- fast, convenient online submission

- thorough peer review by experienced researchers in your field

- rapid publication on acceptance

- support for research data, including large and complex data types

- gold Open Access which fosters wider collaboration and increased citations

- maximum visibility for your research: over $100 \mathrm{M}$ website views per year

At BMC, research is always in progress.

Learn more biomedcentral.com/submissions 